\title{
UPAYA PENINGKATAN AKTIVITAS DAN HASIL BELAJAR FISIKA DENGAN METODE PRAKTIKUM PADA SISWA KELAS XI IPA MAN 1 KALIANDA LAMPUNG SELATAN
}

\author{
Poniman \\ Madrasah Aliyah Negeri 1 Lampung Selatan; e-mail: ponimankal@yahoo.com
}

Diterima: 26 Agustus 2016. Disetujui: 12 Oktober 2016. Dipublikasikan: Oktober 2016

\begin{abstract}
This study aims to increase physics activity learning outcomes with practical methods in class XI IPA1. The study was conducted in two cycles, consisting of: planning, implementation, analysis, reflection. The first cycle is obtained, the students activity consider the teacher's explanation 57.14\%, using the laboratory equipment of $22.86 \%$. cooperation between students in the group $28.57 \%$, asking questions $11.43 \%$, answering teachers questions $45.71 \%$, expressed ideas $8.57 \%$, draw conclusions 42.85\%. make reporting $51.43 \%$, punctuality 42.86\%. Learning outcomes mean 66.60, highs 79.00, lows 53.00, classical completeness 57.14\%. In the second cycle of the student activity increased to $94.28 \%$. Using laboratory equipment $85.71 \%$. cooperation between of students in the group $71.43 \%$, asking the question $40 \%$, answered questions teachers $82.86 \%$, expressed the idea $28.57 \%$, summed $80.00 \%$. make reporting $97.15 \%$, punctuality $85.71 \%$, and learning outcomes mean of 77.80, 89.00 highs, lows 63.00 $88.57 \%$ classical completeness.
\end{abstract}

\begin{abstract}
Abstrak: Penelitian ini bertujuan untuk meningkatkan aktifitas hasil belajar fisika dengan metode praktikum pada siswa kelas XI IPA1. Penelitian dilakukan dua siklus, terdiri dari: perencanaan, pelaksanaan, analisis, refleksi. Siklus pertama diperoleh, aktifitas siswa memperhatikan penjelasan guru $57,14 \%$, menggunakan alat-alat laboratorium 22,86 \%. kerjasama antara siswa dalam kelompok 28,57 \%, mengajukan pertanyaan $11,43 \%$, menjawab pertanyaan guru $45,71 \%$, menyatakan ide $8,57 \%$, menarik kesimpulan 42,85\%. membuat pelaporan 51,43\%, ketepatan waktu 42,86\%. Hasil belajar rerata 66,60, tertinggi 79,00, terendah 53,00, ketuntasan klasikal 57,14\%. Pada siklus kedua aktivitas siswa meningkat menjadi 94,28\%, Menggunakan alat-alat laboratorium 85,71\%. kerjasama antara siswa dalam kelompok $71,43 \%$, mengajukan pertanyaan $40 \%$ menjawab pertanyaan guru $82,86 \%$, menyatakan ide $28,57 \%$, menyimpulkan $80,00 \%$. membuat pelaporan $97,15 \%$, ketepatan waktu $85,71 \%$, serta hasil belajar rerata 77,80, tertinggi 89,00, terendah 63,00 ketuntasan klasikal 88,57\%.
\end{abstract}

C 2016 Pendidikan Fisika FTK IAIN Raden Intan Lampung

Kata kunci: aktivitas, hasil belajar Fisika, praktikum.

\section{PENDAHULUAN}

Keberhasilan siswa tidak terlepas peran aktif guru yang mampu memberi motivasi serta menciptakan iklim belajar yang harmonis, kondusif, menyenangkan, mampu memberi semangat kepada siswa. Rendahnya prestasi belajar dipengaruhi beberapa faktor baik internal maupun eksternal siswa itu sendiri. Faktor internal antara lain minat, bakat, motivasi dan intelegensi sedangkan faktor eksternal antara lain metode belajar, fasilitas, media, proses belajar baik di sekolah maupun luar sekolah. Dengan demikian guru harus menguasai berbagai bentuk metode mengajar, menggunakan metode yang sesuai pada setiap materi yang akan diajarkannya.

Praktikum merupakan salah satu factor yang mempengaruhi hasil belajar siswa dan sangat berperan penting dalam menunjang keberhasilan proses belajar mengajar IPA. Beberapa ahli media pembelajaran mengemukakan slogan dalam proses belajar mengajar yaitu: "if $I$ hear I forget, If I see I remember, If I do I 
understand and I know", bahwa bila saya dengar saya lupa, bila saya lihat saya ingat, bila saya lakukan saya mengerti dan mengetahui. (Nasution, 2005: 4).

Berdasarkan pengamatan dan pengalaman penulis dalam mengajar fisika selama ini, siswa masih mengalami kesulitan dalam mempelajari fisika yang ditunjukan dengan nilai harian yang diperoleh siswa pada akhir pokok bahasan belum memuaskan. Gejala yang tampak pada proses pembelajaran, siswa cenderung bersifat pasif, rendahnya respon umpan balik dari siswa terhadap pertanyaan dan penjelasan guru. Pembelajaran cenderung berpusat pada guru siswa secara pasif menerima materi dari guru sehingga siswa tidak terlatih untuk menemukan sendiri masalahnya. Dalam forum diskusi atau menyelesaikan tugas siswa masih cenderung bertanya pada guru bekerjasama dan memanfaatkan teman sejawat belum terlihat. Penulis menilai bahwa pembelajaran yang berlangsung, masih berpusat pada guru, kurang memanfaatkan laboratorium sebagai tempat melakukan eksperimen siswa.

Maka penelitian ini, ingin mengungkapkan apakah penerapan metode praktikum dapat meningkatkan aktivitas dan hasil belajar fisika pada siswa kelas XI IPA.1 Semester Ganjil MAN 1 Lampung Selatan. Mengingat adanya berbagai keterbatasan, penelitiaan ini difokuskan pada salah satu pokok bahasan pengaruh gaya pada batang pegas dan hukum Hook untuk Memahami konsep getran selaras pada pegas. Rumusan masalah dalam percobaan ini yakni: 1) berapa nilai dari tetapan pegas (k) yang diperoleh dengan cara statis dan dinamis: 2) apa hubungan antara massa (m) dengan panjang pegas (x) dan hubungan massa $(\mathrm{m})$ dengan Periode $(\mathrm{T})$. Penelitian ini pernah dilakukan oleh tim fisika dasar panduan praktikum fisika dasar 1. revisi 1. 2011, tetapi tempat penelitian dan hasil yang diperoleh berbeda pula.

\section{LANDASAN TEORI}

Pratikum berasal dari kata praktik yang artinya pelaksanaan secara nyata apa yang disebut dalam teori. Sedangkan pratikum adalah bagian dari pengajaran yang bertujuan agar siswa mendapat kesempatan untuk menguji dan melaksanakan di keadaan nyata, apa yang diperoleh dari teori dan pelajaran praktik (KBBI, 2001). Proses belajar mengajar dalam ruang lingkup mata pelajaran ilmu pengetahuan alam lebih menitik beratkan pada kemampuan siswa secara ilmiah, yang dalam pelaksanaannya memerlukan kemampuan secara khusus atau dengan kata lain hasil yang diperoleh setelah mata pelajaran tidak hanya berupa informasi pengetahuan saja namun keterampilan penggunaan alat laboratoriumpun bisa diperoleh siswa tersebut.

Menurut Hamalik dalam Arsyad (2000: 15) mengemukakan bahwa pengajaran dalam proses belajar mengajar dapat membangkitkan motivasi dan rangsangan kegiatan belajar bahkan membawa pengaruh psikologi terhadap siswa. Inti proses pengajaran tidak lain adalah kegiatan belajar anak didik dalam mencapai suatu tujuan pengajaran.

Tujuan belajar adalah suatu deskripsi mengenai tingkah laku yang diharapkan tercapai oleh siswa setelah berlangsungnya proses belajar. Tujuan belajar merupakan cara yang akurat untuk menentukan hasil pembelajaran (Oemar Hamalik, 2008: 73).

Menurut Oemar Hamalik (2008: 7375) tujuan belajar terdiri dari tiga komponen, yaitu: 1) Tingkah laku terminal. Tingkah laku terminal adalah komponen tujuan belajar yang menentukan tingkah laku siswa setelah belajar; 2) Kondisi-kondisi tes. Komponen kondisi tes tujuan belajar menentukan situasi di mana siswa dituntut untuk mempertunjukkan tingkah laku 
terminal; 3) Ukuran-ukuran perilaku. Komponen ini merupakan suatu pernyataan tentang ukuran yang digunakan untuk membuat pertimbangan mengenai perilaku siswa.

Oleh karena itu sebagai pengajar, guru harus dapat menentukan kegiatan belajar mengajar yang tepat, khususnya mata pelajaran fisika salah satunya adalah pratikum yang merupakan bentuk pengajaran dimana siswa secara aktif dan langsung dalam usaha memperoleh pengetahuan dan pemahaman teori atau memberikan suatu keterampilan berdasarkan kegiatan ynag telah dilakukan dalam ruang lingkup petunjuk yang telah ada.

Kegiatan praktikum membutuhkan waktu yang lebih lama dibandingkan dengan belajar secara teori. Akan tetapi, masalah tersebut dapat diatasi dengan mengatur waktu dan mengalokasikan sesuai dengan jadwal yang telah direncanakan sehingga kegiatan praktikum dapat berjalan dengan lancar tanpa ada masalah pada pengaturan waktunya.

Menurut Azhar (2002: 10-12)," Belajar yang paling baik adalah melalui pengalaman langsung." Beberapa kelebihan praktikum menurut Azhar (1993: 78): 1) Dalam penyapaian bahan, menggunakan kegiatan dan pengalaman langsung dan konkrit. Kegiatan dan pengalaman demikain lebih menarik perhatian siswa dan memungkinkan pembentukan konsep-konsep abstrak yang mempunyai makna; 2) Lebih realistis dan mempunyai makna, sebab siswa bekerja langsung dengan contoh-contoh nyata. Siswa langsung mengaplikasikan kemampuannya; 3) Para siswa belajar langsung menerapkan prinsip-prinsip dan langkah-langkah pemecahan masalah; 4) Banyak memberikan kesempatan bagi keterlibatan siswa dalam situasi belajar.

Kegiatan demikian akan banyak membangkitkan motivasi belajar sebab kegiatan belajar akan disesuaikan dengan minat dan kebutuhan siswa. Beberapa kelemahan pratikum menurut Azhar (1993: 78), diantaranya: 1) Membutuhkan waktu yang lebih lama dibandingkan dengan belajar secara teori; 2) Bagi siswa yang berusia muda, kemampuan rasional mereka masih terbatas; 3) Menuntut kemandirian, kepercayaan diri sendiri, kebiasaan bertindak sebagai subjek pada lingkungan yang kurang memberikan peran kepada anak sebagai subjek. Mereka lebih banyak diperlakukan sebagai objek; 4) Kesukaran dalam menggunakan faktor subjektifitasnya, terlalu cepat sampai kepada kesimpulan dan membuat generalisasi yang terlalu umum dari pengalaman yang sangat terbatas.

Tujuan praktikum menurut Azhar (1993: 78 ): 1) Keterampilan kognitif yang tinggi: a) melatih agar teori dapat dimengerti; b) agar teori yang berlainan dapat diintegrasikan; c) agar teori dapat diterapkan kepada problema yang nyata 2) Keterampilan afektif: a) belajar kegiatan secara mandiri; b) belajar bekerja sama; c) Belajar mengkomunikasikan hasilnya; c) keterampilan psikomotor: a) belajar memasang peralatan yag benar; b) belajar memakai peralatan tertentu

\section{Aktivitas Belajar}

Aktivitas berasal dari kata dasar "aktif" yang berarti giat; dinamis; atau bertenaga. Aktivitas belajar fisika merupakan kegiatan yang dilakukan siswa dalam proses pembelajaran fisika. Implementasinya, dalam proses pembelajaran, aktivitas merupakan prinsip yang sangat penting, karena pembelajaran tidak akan pernah ada tanpa adanya aktivitas oleh karena itu, diperlukan strategi pembelajaran yang tepat untuk dapat mendorong aktivitas siswa. Menurut Oemar Hamalik (2009;179) menyatakan bahwa aktivitas belajar merupakan kegiatan yang dilakukan oleh siswa dalam kegiatan pembelajaran. 
Aktivitas belajar dapat terwujud apabila siswa terlibat belajar secara aktif.

Adapun jenis-jenis aktivitas dalam belajar yang digolongkan oleh Menurut Paul B. Diedric (dalam Hamalik, 2009:90), jenis-jenis aktivitas dibagi dalam delapan kelompok sebagai berikut: 1) Kegiatan-kegiatan visual: membaca, melihat gambar-gambar, mengamati eksperimen, demonstrasi, pameran, dan mengamati orang lain bekerja dan bermain.; 2) Kegiatan-kegiatan lisan (oral): mengemukakan suatu fakta atau prinsip, menghubungkan suatu kejadian, mengajukan pertanyaan, memberi saran, mengemukakan pendapat, wawancara, diskusi dan interupsi; 3) kegiatan-kegiatan mendengarkan: mendengarkan penyajian bahan, mendengarkan percakapan atau diskusi kelompok, mendengarkan suatu permainan, mendengarkan radio; 4) Kegiatan-kegiatan menulis: menulis cerita, menulis laporan, memeriksa karangan, bahan-bahan kopi, membuat rangkuman, mengerjakan tes dan mengisi angket; 5) kegiatan-kegiatan menggambar: menggambar, membuat grafik, chart, diagram peta, dan pola; 6) Kegiatan-kegiatan metrik: melakukan percobaan, memilih alat-alat, melaksanakan pameran, membuat model, menyelenggarakan permainan, mencari dan berkebun; 7 Kegiatan-kegiatan mental: merenungkan, mengingat, memecahkan masalah, menganalisis faktor-faktor, melihat hubunganhubungan dan membuat keputusan; 8) Kegiatan-kegiatan emosional: minat, membedakan, berani, tenang dan lainlain.

Dari berbagai penjelasan yang telah diuraikan di atas, aktivitas belajar merupakan kegiatan-kegiatan yang terjadi yang dilakukan secara fisik ataupun non fisik yang merupakan tingkah laku individu melalui interaksi dengan lingkungan sebagai hasil belajar mencakup aspek kognitif, afektif dan psikomotorik.

\section{Hasil Belajar}

Menurut Sutiamin (2006:10) Hasil belajar merupakan salah satu faktor penting untuk mengukur keberhasilan seseorang dalam belajar, hasil belajar dapat diartikan sebagai produk dari proses belajar. Sebagai suatu produk, maka hasil belajar sesungguhnya merupakan akumulasi dari berbagai faktor awal, proses sampai dengan hasil.

Menurut Nasution (2006: 36) hasil belajar adalah hasil dari suatu interaksi tindak belajar mengajar dan biasanya ditunjukkan dengan nilai tes yang diberikan guru.

Sedang menurut Salma (2008: 83) mengatakan bahwa "Suatu hasil belajar yang dicapai dalam suatu usaha belajar dalam hal ini adalah mewujudkan nilai dan hasil belajar siswa yang dapat dilihat pada hasil atau nilai yang diperoleh setiap mengikuti tes". Proses belajar mencapai puncaknya pada hasil belajar atau unjuk kerja siswa, hasil belajar merupakan hasil akhir dari suatu proses pembelajaran.

\section{METODE PENELITIAN}

Proses action reasearch, model Kemmis dan Mc Taggart (dalam Arikunto, 2010; Saregar, 2016) dapat visualisasikan seperti gambar 1 berikut,

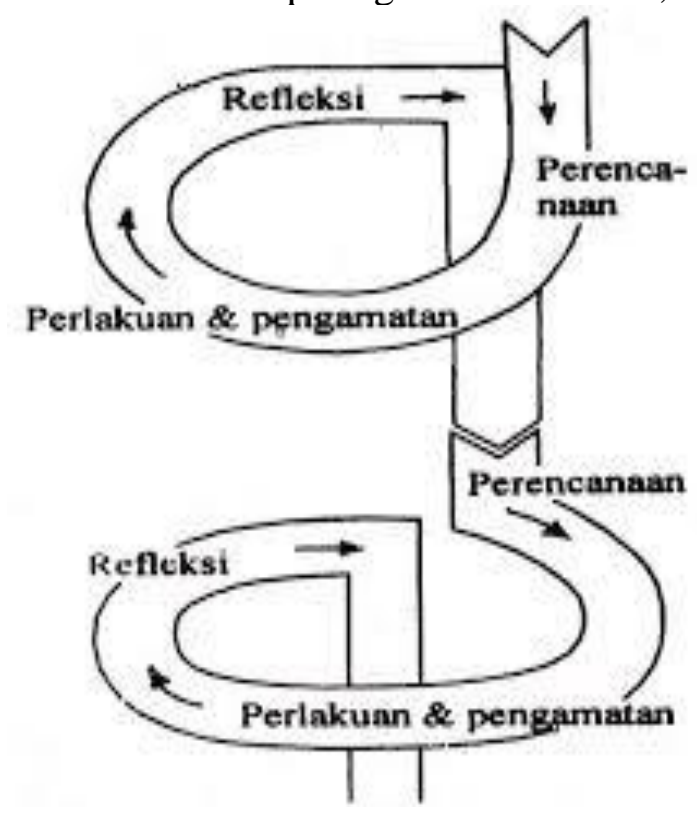

Gambar 1. Siklus Penelitian Tindakan Model Kemmis dan Mc Taggart 
Desain penelitian tindakan kelas ini didasarkan pada konsep pokok penelitian tindakan kelas (action research), yang terdiri dari 4 komponen yaitu perencanaan (planning), pelaksanaan (acting), pengamatan (observing) dan refleksi (reflecting). sehingga pada gilirannya perlu dilakukan perencanaan ulang, tindakan ulang, pengamatan ulang, serta diikuti pula dengan refleksi ulang. Demikian langkah-langkah kegiatan terus berulang dari siklus satu, dua dan seterusnya, sampai sesuatu permasalahan dianggap teratasi dan memperoleh hasil yang ajeg. Jika hasil siklus ke-dua sama dengan siklus pertama, berarti sudah ada keajegan (Arikunto, 2010 dalam Saregar, 2016).

Adapun aplikasi persiklusannya dapat diuraikan sebagai berikut: 1) Tahap perencanaan (planning). Pada tahap ini kegiatan yang dilakukan meliputi: a) Menyusun Rencana Pelaksanaan Pembelajaran (RPP) dan menentukan strategi pembelajarannya; b) Menyiapkan Instrumen Penilaian; c) Lembar observasi; d) Menyiapkan modul praktikum atau lembar kerja siswa; e) Menyiapkan peralatan dan bahan praktikum; 2) Tahap laksanaan (acting). Pada tahap pelaksanaan tindakan dilakukan langkahlangkah sebagai berikut: a) Langkah kesatu, guru menyampaikan tujuan pembelajaran dan memotivasi siswa agar mereka dapat mencapai semua tujuan pembelajaran dan mengkaitkan materi yang dipelajari ke dunia nyata; b) Langkah kedua, guru menyajikan infomasi kegiatan yang akan dilakukan siswa; c) Langkah ketiga, guru menciptakan masyarakat belajar dengan meminta siswa membentuk kelompok; d) Langkah keempat, guru membimbing kelompok-kelompok belajar dalam melakukan percobaan; 3) Tahap pengamatan (observing) Pelaksanaan. tahap ini dilakukan bersamaan dengan tahap pelaksanaan tindakan pembelajaran. Pengamatan dilakukan oleh guru secara langsung. Hasil pengamatan berupa data observasi yang dicatat pada lembar observasi dan nilai tes pada akhir setiap pertemuan; 4) Tahap refleksi (reflecting). Data yang dikumpulkan selama tindakan berlangsung, meliputi: hasil tes dan observasi kemudian dianalisis. Berdasarkan hasil analisis ini, guru melakukan refleksi untuk mengetahui perkembangan kemajuan dan kelemahan yang terjadi. Hasil refleksi ini merupakan masukan bagi guru dalam merencanakan dan melaksanakan tindakan atau strategi perbaikan berikutnya. Refleksi terkait proses pembelajaran juga dapat dilakukan oleh guru bersama siswa.

Pada pelaksanaan siklus 2, berdasarkan dari refleksi siklus 1. Apakah hasilnya sudah memenuhi target yang diharapkan atau belum, jika belum maka penelitian harus dilanjutkan dengan siklus 2. Tahapan siklus kedua ini pun masih sama yaitu perencanaan, pelaksanaan, pengamatan kernudian refleksi. sehingga pada gilirannya perlu dilakukan perencanaan ulang, tindakan ulang, pengamatan ulang, serta diikuti pula dengan refleksi ulang. Demikian langkahlangkah kegiatan terus berulang dari siklus satu, dua dan seterusnya, sampai sesuatu permasalahan dianggap teratasi dan memperoleh hasil yang ajeg. Jika hasil siklus ke-dua sama dengan siklus pertama, berarti sudah ada keajegan (Arikunto, 2010).

Pada siklus kedua dilakukan pembelajaran dengan metode praktikum pada pokok bahasan pengaruh gaya pada sifat elastis benda. Untuk membantu pengamatan peneliti bekerjasama dengan guru mitra (teman sejawat) yaitu salah seorang guru pelajaran fisika.

\section{HASIL DAN PEMBAHASAN Hasil Penelitian}

Aktifitas belajar siswa pada materi indikator pengaruh sifat gaya pada batang pegas dengan metode praktikum disajikan pada tabel berikut: 
Tabel. 1 Aktivitas siswa dari siklus I - II

\begin{tabular}{lcc}
\hline \multicolumn{1}{c}{ Indikator } & \multicolumn{2}{c}{ Siklus } \\
\cline { 2 - 3 } & I & II \\
\hline Penjelasan guru & $57,14 \%$ & $94,28 \%$ \\
\hline $\begin{array}{l}\text { Mempergunakan alat }- \\
\text { alat lab }\end{array}$ & $22,86 \%$ & $85,71 \%$ \\
\hline Kerjasama kelompok & $28,57 \%$ & $71,43 \%$ \\
\hline $\begin{array}{l}\text { Menjawab pertanyaan } \\
\text { guru }\end{array}$ & $45,71 \%$ & $82,86 \%$ \\
\hline Menyatakan ide & $8,57 \%$ & $28,57 \%$ \\
\hline $\begin{array}{l}\text { Mengajukan } \\
\text { pertanyaan }\end{array}$ & $11,43 \%$ & $40,00 \%$ \\
\hline Membuat kesimpulan & $42,85 \%$ & $80,00 \%$ \\
\hline pelaporan & $51,43 \%$ & $97,15 \%$ \\
\hline Pemanfaatan waktu & $42,86 \%$ & $85,71 \%$ \\
\hline
\end{tabular}

Hasil belajar siswa pada materi pengaruh sifat gaya pada batang pegas dengan metode praktikum disajikan pada tabel berikut:

Tabel 2, Hasil belajar dari siklus I - II

\begin{tabular}{lcc}
\hline \multirow{2}{*}{ Nilai } & \multicolumn{2}{c}{ Siklus } \\
\cline { 2 - 3 } & I & II \\
\hline Rata-rata & 66,60 & 77,80 \\
\hline Tertinggi & 79,00 & 89,00 \\
\hline Terendah & 53,00 & 63,00 \\
\hline $\begin{array}{l}\text { Ketuntasan } \\
\text { Klasikal }\end{array}$ & 57,14 & 88,14 \\
\hline
\end{tabular}

\section{PEMBAHASAN}

Penelitian tindakan kelas ini terdiri dari 2 siklus. Setiap siklus terdiri 1 kali pertemuan yang sesuai dengan prosedur penelitian. Pada siklus 1, materi yang digunakan adalah pengaruh gaya pada batang pegas, diperoleh data pada Tabel 1 aktivitas siswa, menunjukan $57,14 \%$ memperhatikan penjelasan guru, 22,86\% aktivitas kemampuan siswa mempergunakan alat-alat laboratorium belum begitu baik, hal ini terlihat ketika siswa diminta untuk merakit alat statif, siswa saling mengandalkan satu sama lainnya. Sementara itu kerjasama antara anggota kelompok hanya mencapai $28,57 \%$, ini menunjukan kerjasama antara anggota kelompok belum terbiasa.

Menurut pengamatan peneliti ditemukan bahwa bertanya tidak hanya terjadi antara guru dengan siswa, tetapi juga terjadi antara siswa dengan siswa. Pertanyaan yang diajukan guru digunakan bukan hanya mengajak siswa terlibat dalam proses pembelajaran tetapi juga digunakan untuk menuntun siswa dalam menemukan konsep materi pelajaran. Dalam Tabel 1 juga memperlihatkan, masih banyak siswa yang belum berani mengajukan pertanyaan dan menyataan ide. Hal ini terjadi karena siswa sulit untuk menyampaikannya. Siswa yang menjawab pertanyaan dari guru masih relatif sedikit yaitu sebesar $45,71 \%$. Jawaban siswa masih banyak yang belum sempurna. Kemampuan siswa dalam menyatakan ide masih sangat rendah yaitu $8,57 \%$, siswa merasa sulit untuk menyatakan ide secara langsung. Demikian juga dalam mengajukan pertanyaan masih rendah $11,43 \%$. Hal ini terjadi karena siswa nampak belum memiliki keberanian, pertanyaanpertanyaan yang diajukan siswa masih merupakan pertanyaan yang berkaitan dengan pengetahuan kognitif dan pertanyaan pada langkah-langkah percobaan. Kesulitan dalam mengkomunikasikan pemahaman mereka. Hal ini dapat diketahui ketika siswa diminta untuk merumuskan kesimpulan dan menyampaikan secara lisan, seperti terlihat pada tabel kemapuan membuat kesimpulan sebesar 42,85\%. Pada kegiatan pelaporan belum berjalan dengan lancar karena siswa belum dapat menyusun hasil kegiatan kelompok secara baik dan sistematis. Persentasi siswa untuk penyusunan laporan dengan baik mencapai $51,43 \%$. Dalam pemanfaatan waktu belum sama dengan alokasi waktu yang tersedia, hanya $42,86 \%$ yang dapat memanfaatkan waktu dengan baik, hal ini disebabkan siswa belum dapat bekerja secara sistematis secara teknis.

Hasil belajar siswa tampak pada Tabel 2 yang diperoleh dari hasil post test yang diberikan guru pada akhir pertemuaan. Pada siklus I terlihat nilai 
rata-rata 66,60 dengan nilai tertinggi 79,00, terendah 53,00 dan ketuntasan klasikal $57,14 \%$. Dari siklus 1 diadakan refleksi untuk siklus 2.

Hasil refleksi siklus 1 adalah

1. Guru memberi penjelasan yang lebih menarik dan berbahasa yang jelas.

2. Guru memberi pelayanan dalam bentuk pertanyaan yang sederhana dan mudah dipahami.

3. Guru memberi pelayanan pada siswa yang kesulitan mengajukan pertanyaan dengan cara membimbing membuat pertanyaan bertingkat.

4. Guru membimbing kelompok siswa dalam menyatakan ide dengan cara mengajak siswa berpikir tentang halhal yang ada disekitarnya.

5. Guru menunjukan urutan langka kerja seperti pada LKS dan memberikan motivasi untuk tidak ragu-ragu dalam menggunakan alat agar siswa lebih mudah dan trampil dalam melakukan percobaan.

6. Guru menyarankan agar siswa menyusun hasil percobaan dengan sistematis dan berkomunikasi dengan guru bahasa Indonesia.

Penelitian siklus dua dilakukan pada pokok bahasan hukum hook dengan melakukan tahapan sama seperti pada siklus 1 yang berbeda pada tahap pelaksanaan dilakukan perbaikanperbaikan menindak lanjuti hasil refleksi siklus satu, yaitu meningkatkan layanan siswa dalam bentuk bimbingan pada semua kelompok yang mengalami kesulitan dalam menyelesaikan masalah.

Kondisi pembelajaran siklus 2 mengalami perubahan begitu pula dengan hasil belajar yang dihasilkan. Hal ini terlihat pada Tabel 1 dan Tabel 2.

Aktivitas siswa pada siklus kedua menunjukan adanya peningkatan ssebesar $35,14 \%$, ini berarti siswa sangat antusias dalam memperhatikan penjelasan yang disampaikan oleh guru, sehingga masingmasing siswa dapat memahami materi pembelajaran. Terampil dalam menggunakan alat-alat laboratorium juga sangat tampak terlihat, $83,71 \%$ menunjukan nilai yang baik. Hal ini terjadi karena sudah mulai terbiasa menggunakan alat, rasa takut sudah bisa diatasi, tidak terlihat lagi mengandalkan teman masing-masing semangat untuk melakukan percobaan bahkan sudah dapat mengidentifikasi alat-alat yang akan digunakan dalam percobaan. Namun demikian tetap masih ada siswa yang mengalami kesulitan dalam melakukan percobaan. Hal ini terjadi karena siswa tersebut kurang memperhatikan penjelasan guru. Penerapan komponen masyarakat belajar sudah baik. Selama proses pembelajaran sudah terjadi komunikasi antar siswa untuk berbagi gagasan, siswa mampu bekerjasama dan berbagi pengalaman sudah tidak tampak dominasi dari salah satu siswa. Dalam hal mengajukan dan jawab pertanyaan masing-masing terdapat peningkatan sebesar, $28,57 \%$ dan $37,15 \%$, pertanyaan yang diajukan sudah didasarkan hasil percobaan dan yang ada hubungannya dengan konsep/prinsip. Dalam menjawab pertanyaan siswa sudah memikirkan hubungan dan perbedaan yang ditentukan sesuai dengan konsep. Siswa yang menyatakan ide mencapai $28,57 \%$ dalam menyatakan ide sudah mendasar pada hasil pengamatan. Pada kegiatan pelaporan sudah berjalan dengan lancar karena siswa sudah mulai terbiasa membuat laporan ilmiah secara baik dan sistematis. Persentasi siswa untuk penyusunan laporan dengan baik mencapai $97,15 \%$ terjadi peningkatan $47,72 \%$. Sebagian besar siswa sudah dapat menarik kesimpulan apa mereka lakukan ini terlihat dari persentase peningkatan siswa yang mampu menarik kesimpulan sebesar 80\%. Pada saat pemanfaatan alokasi waktu $85,71 \%$ sudah tepat dengan mengurangi pekerjaan teknis yang tidak perlu. Serta sudah fokusnya siswa sehingga waktu lebih efektif. Sesuai teori menurut Paul B. Diedric (dalam 
Hamalik, 2009:90), jenis-jenis aktivitas poin ke-6 dan teori menurut Salma (2008; 83) tentang hasil belajar, diperoleh peningkatan aktivitas dan sekaligus peningkatan hasil belajar siswa pada siklus 2. Dari tabel 4.2 terlihat Nilai ratarata 66,60 meningkat menjadi 77,80 . Sementara itu nilai tertinggi 79,00 meningkat menjadi 89,00 , serta nilai terendah $53,00 \%$ meningkat menjadi 63,00. Dengan demikian akan menaikkan pula ketuntasan klasikal semula $57,14 \%$ menjadi $88,57 \%$.

\section{SIMPULAN}

Berdasarkan hasil pembahasan, maka penelitian ini dapat disimpulkan bahwa penerapan metode praktikum dapat meningkatkan aktivitas dan hasil belajar fisika pada siswa kelas XI IPA.1 Semester Ganjil MAN 1 Lampung Selatan Tahun Pelajaran 2014-2015.

\section{SARAN}

Berdasarkan hasil penelitian ini disarankan untuk mengembangkan media pembelajaran praktikum fisika untuk pokok bahasan lainnya sehingga dapat meningkatkan hasil belajar fisika siswa.

\section{DAFTAR PUSTAKA}

Arsyad, Azhar. (2002). Media Pengajaran. Jakarta: PT Raja Grafindo.

Nasution, S. (2005). Teknologi Pendidikan. Jakarta: Bumi Aksara.

Nasution, S. (2006). Asas-asas Kurikulum. Jakarta: Bumi Aksara

Wiriaatmadja, Rochiati. (2006). Metode Penelitian Tindakan Kelas. Bandung: PT Remaja Rosda Karya.

Hamalik, Oemar. (2009). Kurikulum dan Pembelajaran. Jakarta: Bumi Aksara.

Salma, Dewi. (2008). Prinsip Disain Pembelajaran. Jakarta: Kencana.

Saregar, A. (2016). Pembelajaran Pengantar Fisika Kuantum dengan
Memanfaatkan Media PhET

Simulation dan LKM Melalui

Pendekatan Saintifik: Dampak

Pada Minat dan Penguasaan

Konsep Mahasiswa. Jurnal Ilmiah

Pendidikan Fisika Al BiRuNi, 5(1), 53-60.

Sutiamin. (2006). Peningkatan

Pembelajaran Fisika Melalui

Pendekatan Problem Solving pada materi fisika dikelas VIII c SMP N.

7 gorontalo. Skripsi: Universitas Negeri Gorontalo.

Tim fisika dasar revisi 1, (2011). panduan praktikum fisika dasar 1, surabaya: Unipress.

Arikunto, S. (2010). Prosedur Penelitian (suatu pendekatan praktik) Edisi Revisi. PT. Rineka Cipta. Jakarta 